\title{
Deathless after Death: Humanize the Tradition and Celebrate of Death in Java
}

\author{
Sumekar Tanjung ${ }^{1, *}$ \\ ${ }^{1}$ Department of Communications, Islamic University of Indonesia, Yogyakarta, 55584, Indonesia
}

\begin{abstract}
This paper aims to describe important side about death conception in Java, especially Bejikarto's people as one of Javanese in Yogyakarta. This research located in Yogyakarta city and take the informants purposively. Technique of collecting data doing through participate observation and in-depth interviews, while the data analyzed by ethnographic descriptive. For Javanese, death is not the end of the journey in this temporal world. Death as a manifestation of the body's extinction and the new life's genesis that is eternity. In Javanese culture, all of the life and death's process have concept and control. Death upheld to maintain harmonious relations with others, with nature occult or supernatural with God. To celebrate the death of the bodies considered as an appreciation, respect, and the act of a religious nature. In Javanese, human is the unity with macrocosm. Celebration of death is reflection of Javanese desire in order to reach manunggaling kawula lan gusti (unification with God).
\end{abstract}

\section{Introduction}

Bejikarto is located about 15 kilometers east of the main border city of Yogyakarta and 10 kilometers north of Prambanan Temple. The village is in the midst of large farms and lush, which is the source of village economy. Communication with the surrounding villages and the town is quite smooth and openness, with adequate infrastructure support.

In Javanese people, death is not seen as a problem to arbitrarily decide the common thread between the spiritual and the physical body. Death upheld and generate social realities in their traditions. Love of the Javanese in Javanese his identity cannot be dilunturkan dogma other teachings, even his own religion. An understanding of all conceptions of life and death can be obtained through deductive paradigms scripture. Meanwhile, local traditions departing from inductive paradigm, where the tradition of ancestral become the main handle. When religion sign in Java, both paradigms are met. Both push and pull each other in the form of acculturation and syncretization. Therefore, Javanese adherents of all religions, spiritualism has an attitude and thoughts are relatively common, and they are the true Javanese. This means more emphasis on those who carry out their religious beliefs mingled with Java.

Generally, Javanese form of belief in God are non-doctrinal, not stuffy, and openned. According Bejikarto people, Gusti Pangeran (God) is Tan Kena Kinaya Ngapa (immutable

\footnotetext{
*Corresponding author: sumekar.tanjung@yahoo.com
} 
and cannot be instance). They allegorized Gusti Pangeran relationship with humans symbolically, koyo kodhok kinemulan ing leng (frogs swaddling burrows and frog swaddled burrows). The distance between God and creation are considered not measurable anymore, unlimited, and close but not touching (adoh tanpa wangenan, cedhak tanpo senggolan). That is why a lot of people trying to exploit the symbolism of Java on the song Macapat to achieve and get closer to the Gusti Pangeran (God).

"For Javanese people, the most important thing is to know ourself. And it also means, recognize and honor that God is free to move hearts of everyone. Not as if religion is a private matter, but because the person himself must feel for where came from, and where will go, God called him." (Mandi, September 25, 2014)

Those statement supports Javanese expressions that hate dogmatism, exclusivism, fanaticism, and arrogance as disclosed Mandi as doyen of Bejikarto. In Javanese culture, autonomy for people to find themselves at the bottom of his soul, the coordination of God is very respected.

According Ciptoprawiro in Prabowo [1], Javanese philosophy throughout its history has always conclude that God is sangkan paraning dumadi (origin and the return of all instance). When death comes, there are shapes and forms such as human self that comes out of the body and luminous white, Bejikarto people refers to it as mayangga seta. If the shape already seen, then silence, and silence is considered as an effort to unite themselves with God when it dies.

Javanese literature do not view death as the opposite of life. Therefore, the concept of death is seen as a result of their birth. In short, if there is no birth, then during which there will be no death. Meanwhile, for Bejikarto people, life always comes before and after birth. So death is often expressed as mulih mulo mulanira (back to origin) in Serat Wedhatama on one couplet of Pucung song [2]. This implies that death is not the end of the journey in the mortal world.

Bejikarto people believes that live just as the same as allusion, urip natural neng donyo iku mung nunut ngombe (live in this world just stopped for drink). The word "drink" interpret as transience, when drink is enough, then the journey to the final destination can be resumed. Man must remember that life journey will follow later. Given that there are three concepts of Javanese life cycle on great dharma. Javanese people often refer to tigaan concept. Purwa (beginning) as a preliminary step of man being born, madya (center) is a step in the life of man facing older adults, and wasana (end) is the final stage of an elderly man to dying [3].

By Mandi's statement, the three degrees of dead are distinguished in terms of procession or treatment when the remains will be interred.

"Death is loss of the life of body. Death has three degrees. The first is main death, the death of a man of honor. Intermediate die, natural death or ordinary death like most people. Third degree, nistha death, death from suicide or accidents." (September 25, 2014)

In Serat Asmaralaya described how man who is facing death's door. Asmaralaya are metaphors of life of every human being. Figuratively question is think of dying or death of human consciousness. That God is essentially intangible and enveloping light emanating universe. If the time of death has arrived, there are shapes and forms such as himself out of the body and luminous white (mayangga seta). If the kind of shape it hass been seen, then silence, and silence is an attempt to unite ourselves with God.

\section{Method and Participants}

Communications, rather than specific languages, provide the frame of reference for analyzing the place of language in any particular society or culture. The focus of studies in 
the field is on individual speech communities, which are clusters of people using common signs to communicate. Particularly, communication ethnography is interested in the way that communication within a speech community is organized into various systems of communication events and how they interact with every other system in the culture. It looks to answer the basic question of what a speaker needs to know to communicate correctly and appropriately within a given speech community and how a speaker learns to do this. Researcher analyze different speech situations, such as ceremonies, or speech events, greetings or compliments, to determine how their structure and content are culturally determined. Regardless of the topic of the study, researchers in the ethnography of communication focus on a speech community. The potential participants for these research were two local residents in Bejikarto. The actual participants at each meeting varied depending upon who showed up or asked to be present.

\section{Results and Discussion}

Among the causes of death are suffering. The nature of this illness as well as death, easily happen anytime. For Bejikarto's people, pain is a matter of comfort and discomfort. Dul Sadin, who is resident in this village. He is second child of five siblings. He had eight siblings before, three others were died just for one reason: masuk angin (catch a cold).

Masuk angin is a symptom of getting sick (usually the incubation period of getting flu or cold). The symptoms are feeling dizzy, body temperature is above normal (but feel cold, like a fever), feel sick inside stomach (wanting to throw up, similar to feeling seasick if we have ever been in that situation), and cold sweats. Masuk angin is the ordinary Indonesian's term for feeling unwell. Some peoples are so vulnerable to changing weather, from dry season to rainy season (we call this pancaroba period in changing weather or season), and they blame the wind as the cause. It is called masuk angin because the wind gets into body. If we hang out all night long (begadang), short of sleep or rest and get wind into our body (night wind), you could catch masuk angin and feel unwell when you wake up in the morning.

For Javanese people, masuk angin has emerged as the concept of pain in the form of discomfort, discomfort in the body, believed that caused by the influence of the wind. Actually, masuk angin is not a medical term, but people called it. Presenting symptoms include abdominal bloating, nausea, pain, plus could not fart and burp [4]. For Javanese, winds are said to fall into human body through the pores of human body as well as babahan hawa sanga (there are nine-holes in human body). As a result of the wind elements that enter to body of excess body imbalance. For Javanese people, health is being balance, while illness, injuries and misfortunes regarded as an imbalance.

Due to differences between Javanese concept of medical and then masuk angin was viewed differently by two sides. There is no medical terminology for entry into masuk angin that the wind is only considered as a collection of symptoms of a disease. The medical side is equal to mention catch a cold as same as influenza. Masuk angin is considered to be a symptom of different diseases such as influenza, hypertension, diabetes, hepatitis, or post-traumatic stress. Therefore, catch a cold will be treated by medics based on the symptomatically felt by the patient.

"When I was catch a cold, my eyes felt heavy while opened. My body felt lazy when I was used for work. If there is spare time, so can only be used to bedrest. Just when I smoke, it tasted was bad, bitter tongue, it was definitely I getting catch a cold, " (Sud, September 25, 2014).

Generally, people with masuk angin feels weak, lethargic, and mouth is not delectable to eat and drink. Javanese distinguished cold weight basis mild symptoms, more or less the number of symptoms as well as the ease of the process of healing. Late masuk angin 
(kasep), are allowed by the sufferer so bring sudden death. As a result many sudden deaths are often preceded by malaise, shortness of breath or out a lot of sweat. The expression of traditional healer, Kelik confirmed that, "Angin duduk it should start from ordinary cold, but not felt. It is dangerous because not doing any work just sat there, suddenly died instantly."

The doctor who practice medicine both in health centers, hospitals and private practice patient often find a common complaint that his body does not feel good. They told the doctor that he was prone to colds. Prior to their doctors already performed kerokan (drawing an oiled coin over skin repeatedly until skin turns bright red, it makes the wind exit from body and will get well), herbal drink, and take a pill kecethit (despite it was name pills back pain or twisted pain, but people in rural areas believe that this pill to cure various diseases). Therefore, they went to the doctor who is considered more knows because it has a complete medical equipment. Shortly, all the discomfort or discomfort is felt, they give the term as colds.

Medical systems in traditional societies have different concept of health and illness, as well as treatment efforts. In Javanese people, Foster and Anderson [5] classify the causes of disease ascribed personalistic system or naturalistic system. In personalistic concept, the disease is believed to be the intervention of an intermediary for the active form of magical or non-human. In Bejikarto society, they call it as unreasonable or unnatural disease. These types of diseases such as kelebon, digawe wong, kualat, and kebendhu. The healing is done through ceremony or offering to neutralize cause pain. Naturalistic concept is regarded as lumrah (proper) or natural disease. Usually affecting the health of the body is the weather, food, bacteria, and toxins.

Views of the health anthropologists divide the disease into three health trust model, the magico-religious models, biomedical models, and holistic models. Javanese society which has strong traditional system, all illness is described in a holistic manner. This model emphasizes the aspects of harmonization or balance the body, regarding environmental, social, cultural, and behavioral. A healthy body condition is seen as a state of mind or a balance between the physical and the mental. Javanese sighted, "batin karep, raga nututi", meaning if the mind wills, the body too. That the body, mind, and spirit or sukma (soul) is a unity of mutually influential.

Javanese people are understood that the body is maintained by kakang kawah adhi ariari (everyone has a twin in their life), so human life survive they must understand the universe as a symbol of God's power. It includes four elements, kawah (fetal membrane) for the east, blood fo the south, tali pusar (umbilical cord) for the west, and placenta for the north, which serves to maintain physical and mental health in order to keep in equilibrium, in the context of memayu hayuning bawana (man must be always maintain harmony and balance) Healing intended to restore the balance. Meanwhile, cured or dead, do not know when it happened.

\section{Humanize the tradition}

In Bejikarto and other region in Java, to celebrate death of the bodies considered as an appreciation and respect that should be perpetuated. Even been understood together that event tahlilan a ceremonial ritual is usually done as a generality society. And their relatives, handai taulan (friends) and neighbors who all are men (because that was involved in this ritual are male), do dzikir, while certain prayers to be sent to the corpse.

Rila or sincere, means let everything consciously, as a guideline though often difficult to obtain, but always endeavored everyone. In Javanese philosophy, bamboo philosophy adapted to central element of Javanese culture, namely rila (sincere), and nrima (grateful), and sabar (patient). 
In Bejikarto, this ceremonial usually has done after burial ceremonial on afternoon before maghrib (sunset call to prayer). Selamatan on third days of death (nelung dina) is intended as an attempt heir to honor the dead. In this regard, they believe that the spirit of the deceased still inside the house. But the spirit was not in bed anymore. Spirit is already wandering to find a way and easily leave the house. After the spirit is considered out of the house, then held mitung dina (seventh days of death). Spirit that has come out to be paused in the courtyard. To ease the way, the guests held tahlilan to pray. "Tahlilan means read tayibah sentences. The completion of the guests later given bancakan rice and side dishes."

The term of bancakan on bancakan rice is likely to come from the Pungkur, made of woven bamboo distance tenuous. This webbing called a rack. Later developed and adjusted to Bancak. In addition to the mention of rice bancakan, some are calling it a blessing rice (from Arabic baraka).

On the fourteenth day of death, the spirit has been toward the grave. Given offerings also vary. It is intended as offerings to the spirits and bodies should be enhanced, such as blood, flesh, nails, hair, bones, and muscles [6]. To enhance all of them, do nyatus dina or one hundred days of death. Grain is almost the same, the difference is only in the stocks, sticky rice and compote. Pasung that made such a mountain (payung) of jackfruit and filled material from wheat. Its meaning is that the dead get an payung (protection). Because the person who died is like going through a long and hot, then for him made of sticky rice as lemek (base), so that the feet are not hot. Ketan also significantly raketan, it means to closer to God. Also equipped compote dish which comes from the creator of universe or kolaq (God is The Creator). With this kind of dish, expected dead will smoothly facing The Creator. It then lasts up to one year and two years death of death.

On the one thousand days (nyewu dinane), relatives and neighbors came to donate (give money donations). This tradition is expected to entertain the bereaved family as well as making the message that living also must be followed (death) at a later date. Is also inseparable presented their supper each event held. Model presentation of the dishes are usually varied, depending customary walk at the venue. But the entree menu was more than modest, or tends to resemble a festive menu of dishes that smell. If they were not taking food after tahlil, usually selamatan nyewu put a meal together. After eating together and held a feast. This event so impressed a little party and become a norm.

\section{Conclusion}

It should be noted, all the conceptions that has been described merely formal phenomenon. Melee core Javanese people to pick up and interpret the human life cycle process can not be described by anyone. In his search, they often hit a lot of things and it all comes down to the individual spiritualism. The point of the highest value, Javanese spiritualism hopes to reach ngangkah ningrat nunggal Hyang (reach the silence on the upper level one with God) [7]. A number of studies, including this paper, only slightly touched on the concept of death in Java.

\section{References}

1. P. D. Prabowo, Pengaruh Islam dalam Karya-karya R.Ng.Ranggawarsita (Narasi, Yogyakarta, 2003)

2. Ki Sabdacarakatama, Serat Wedhatama: Karya Sastra K.G.P.AA. Mangkunegara IV (Narasi, Yogyakarta, 2010)

3. S. Endraswara, Mistik Kejawen: Sinkretisme, Simbolisme dan Sufisme dalam Budaya Spiritual Jawa (Narasi, Yogyakarta, 2006) 
4. A, Rustami, A-Z Tips Hidup Sehat Sehari-hari (Wahana Totalita Publisher, Yogyakarta, 2009)

5. M. Sudarma, Mengenal Variasi Layanan Pengobatan Alternatif. Sosiologi untuk Kesehatan (Salemba Medika, Jakarta, 2008)

6. T. W. Bratawidjaja, Thomas Wiyasa. Upacara Tradisional Masyarakat Jawa (Sinar Harapan, Jakarta, 1993)

7. H. Mulyani, J. K. J. 2, 115 (2006) 